\section{Fruit Set of Triploid Watermelons as a Function of Distance from a Diploid Pollinizer}

\author{
D. Scott NeSmith ${ }^{1}$ \\ Department of Horticulture, Georgia Station, Griffin, GA 30223-1797
}

John R. Duval ${ }^{2}$
University of Florida, GCREC-Dover, 13138 Lewis Gallagher Road, Dover,
FL 33257

Additional index words. seedless watermelon, pollination, pollinizer ratio, Citrullus lanatus

Abstract. During 1998 and 1999, 'Genesis' triploid watermelons [Citrullus lanatus (Thunb.) Matsum. \& Nak.] were grown in large blocks with a single row of the diploid 'Ferarri' planted as a pollinizer in the middle. A once-over harvest each year was made in harvest lanes $0,1.5,3.0,4.5,6.0,7.5$, and $9.0 \mathrm{~m}$ perpendicular distances from the pollinizer row. Individual fruit were weighed and counted. Data from both years indicated a similar distribution of triploid fruit with respect to distance from the pollinizer row. The greatest number of triploid fruit per unit land area was in the harvest row $3.0 \mathrm{~m}$ from the pollinizer row. When distance from the pollinizer row was $6.0 \mathrm{~m}$ or greater, triploid fruit numbers diminished substantially. Yield estimates made each year using the fruit density data suggested that a 1 pollinizer : 4 triploid ratio gave the maximum total triploid fruit yield per hectare for 1.5-m row spacings. These results should prove useful in designing field planting strategies to optimize triploid watermelon production.

Triploid, or "seedless", watermelons are becoming increasingly popular among consumers. Marr and Gast (1991) indicated that consumers were willing to pay $50 \%$ more for seedless watermelons than for traditional seeded watermelons. Karst (1990) suggested that there is a potential for seedless watermelons to gain up to $50 \%$ of the market share. Because of this enthusiasm of consumers for seedless watermelons, growers are also becoming more interested in producing the specialty crop. Many traditional seeded watermelon cultural practices can be utilized in growing triploid watermelons, but there are a few key differences. A major difference is that triploid watermelons are sparse pollen producers; therefore, a source of pollen (traditional diploid watermelon cultivar) must be planted with triploids (Maynard and Elmstrom, 1992).

There are few published data on the pollinizer frequency requirement for optimum pollination and fruit production of triploid watermelons. Kihara (1951) suggested that one diploid pollinizer per four to five triploid

Received for publication 10 Dec. 1999. Accepted for publication 26 June 2000. A contribution of the Univ. of Georgia Agricultural Experiment Stations, Georgia Station, Griffin. This research was supported by state and Hatch Act funds allocated to the Georgia Agricultural Experiment Stations. The cost of publishing this paper was defrayed in part by the payment of page charges. Under postal regulations, this paper therefore must be hereby marked advertisement solely to indicate this fact.

'Professor. E-mail address: snesmit@gaes.griffin. peachnet.edu

${ }^{2}$ Assistant Professor. findings. The objective of this research was to determine pollinizer frequency requirements for optimizing triploid watermelon production per unit land area.

\section{Materials and Methods}

In 1998 and 1999, 'Genesis' (Shamrock Seed Co., Salinas, Calif.) triploid watermelons were grown in a field with 'Ferrari' (Shamrock Seed Co.) as a pollinizer at the Georgia Experiment Station in Griffin. The soil was a Cecil sandy clay loam (clayey, kaolinitic, thermic Typic Hapludult). The design was a single factor (distance), replicated experiment, which consisted of a single row of the pollinizer ('Ferrari') with six rows of the triploid ('Genesis') planted on either side. Four large blocks or replications of the planting design were established each year. Row width used was 1.5 $\mathrm{m}$, in-row spacing of plants was $1.2 \mathrm{~m}$, and individual rows were $24.4 \mathrm{~m}$ long. A buffer distance was left between blocks so that the closest distance to a pollinizer plant for any triploid would be in its own block. All plants were established using 5-week-old transplants. Field planting dates were 20 May 1998 and 18 May 1999. Fertilization, pesticide application, and irrigation practices recommended by the Univ. of Georgia Cooperative Extension Service were used in growing the crop (Mizelle, 1988). Pollination relied solely on natural pollinators; no supplemental bees were used.

Once-over harvests of 'Genesis' fruit occurred on 4 Aug. 1998 and 10 Aug. 1999. Each $1.5-\mathrm{m}$ wide row was harvested separately. All fruit $>10 \mathrm{~cm}$ in diameter were harvested and weighed. The harvest strategy provided $1.5 \times 24.4-\mathrm{m}$ harvest lanes that had centers $1.5,3.0,4.5,6.0,7.5$, and $9.0 \mathrm{~m}$ perpendicular distances from the center of the pollinizer row. The triploid watermelons that were in the pollinizer row (due to vine growth

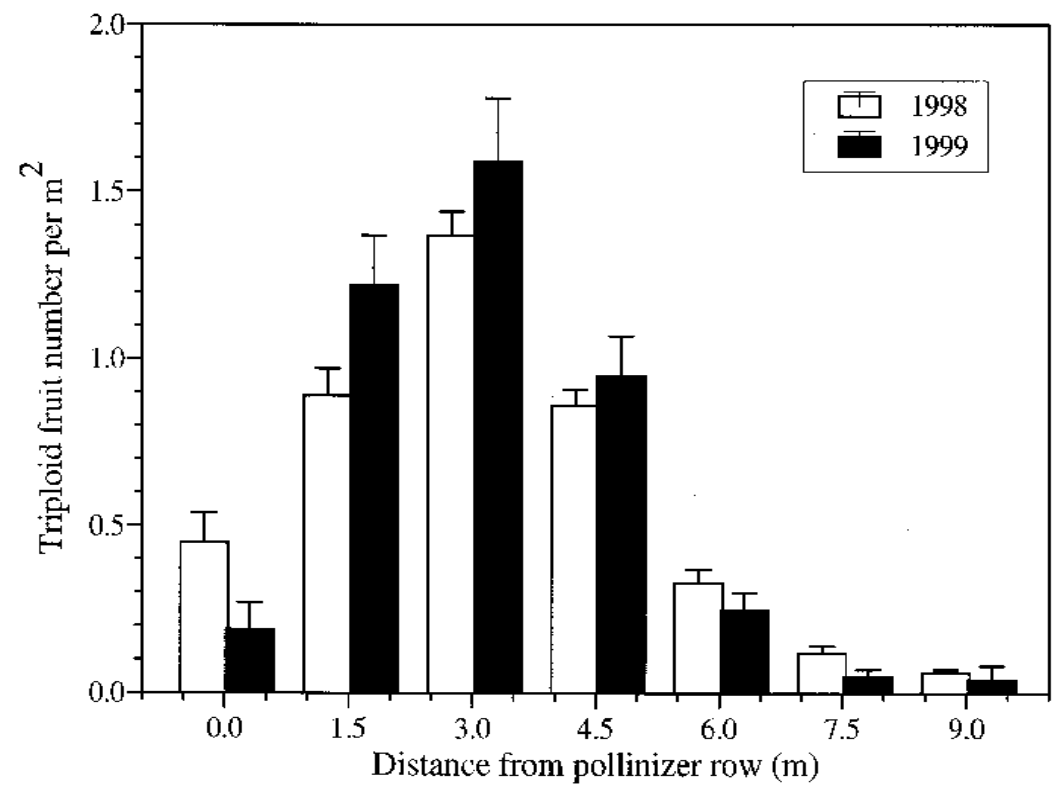

Fig. 1. Fruit number of 'Genesis' triploid watermelon as a function of distance from pollinizer row during 1998 and 1999 at Griffin, Ga. The pollinizer was 'Ferrari'. Each vertical bar represents one 1.5-m-wide row. The 0 distance represents the location of the pollinizer row. Standard errors are depicted by vertical lines. 


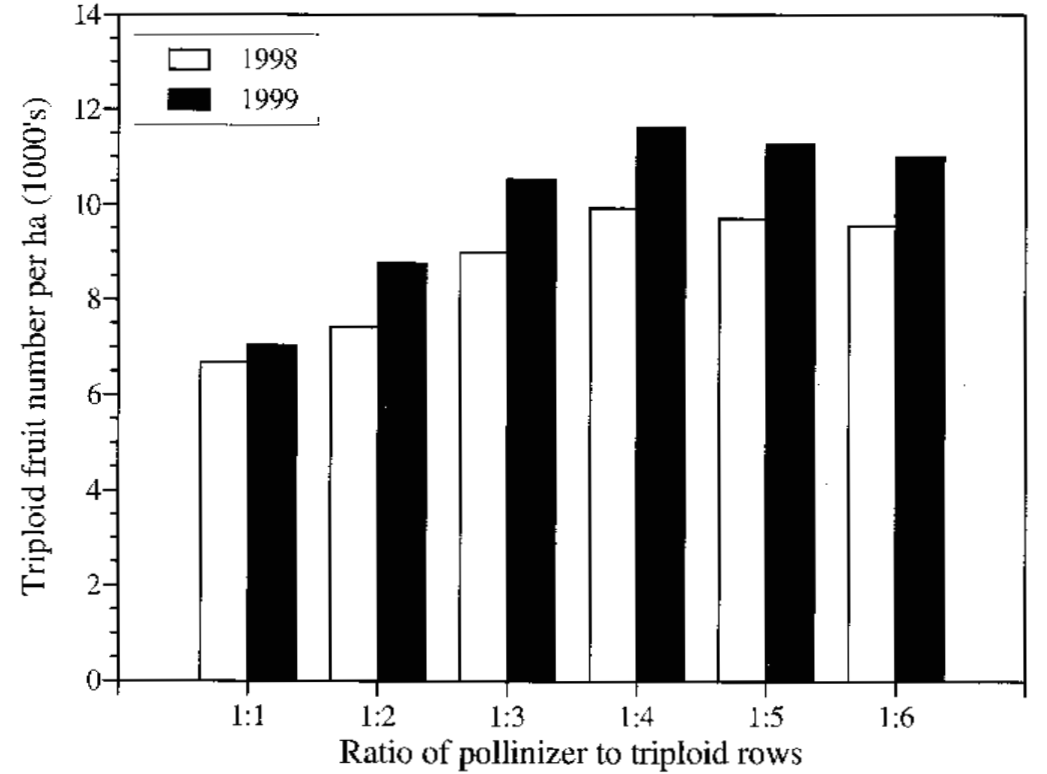

Fig. 2. Estimates of yield (total fruit number/ha) of 'Genesis' triploid watermelon in response to different pollinizer : triploid row ratios during 1998 and 1999. The pollinizer was 'Ferrari'. Estimates are based on $1.5-\mathrm{m}$ row widths.

across rows) were also harvested ( $0 \mathrm{~m}$ from the pollinizer). Harvest lanes of the specified distances were designated on each side of the pollinizer row (east and west) to determine if there was a "directional" effect on fruit density.

\section{Results and Discussion}

Overall, fruit yield for the rows of 'Genesis' plants varied depending on their distance from the pollinizer row (Fig. 1). The patterns of fruit density across the rows were similar for both years. The pollinizer row itself $(0 \mathrm{~m}$ distance $)$ had some triploid watermelons because of vine growth from nearby plants. The first triploid row adjacent to the pollinizer had a substantial number of 'Genesis' watermelons, but the greatest number of seedless watermelons per unit area were present in the second row $(3.0 \mathrm{~m}$ distance) away from the pollinizer each year. The number of triploid watermelons diminished by $37 \%$ to $40 \%$ from the second to the third row ( $4.5 \mathrm{~m}$ distance). The remaining rows (distances of $6.0,7.5$, and $9.0 \mathrm{~m}$ ) set very few fruit, suggesting that distances of $6.0 \mathrm{~m}$ or greater from the pollinizer row are too great for adequate pollination, either because of the distance from the pollen source, or pollen dilution and/or lack of bee visits.

Directionally biased pollen flow was not apparent in the planting blocks of these experirows planted equal distances on either side of the pollinizer row (data not shown). Also, there were no differences in average individual fruit weight or percentage of marketable fruit (data not shown) from the different harvest lanes, only in total fruit number per unit area.

Using the fruit density results from the 1998 and 1999 field experiments, yield projections for different pollinizer : triploid ratios were calculated (Fig. 2). Estimates of fruit yield/ha increased with increasing number of triploid rows up to a ratio of one pollinizer to four triploid rows in both years. A trend toward declining yields/ha was apparent as the number of triploid rows per pollinizer row increased beyond four. Triploid yield (fruit/ ha) for the current, commonly used ratio of $1: 2$ ments. Fruit yields were similar for triploid (every third row a pollinizer) was $25 \%$ less than that resulting from the 1:4 ratio in 1998 and 1999.

The triploid yield estimates in these experiments were based on $1.5-\mathrm{m}$ row widths. This would probably be very acceptable for triploid watermelons, since vine coverage area tends to be smaller than that of traditional seeded watermelons. NeSmith (1993) reported that diploid watermelons grown in 1.5 -m-wide rows at inrow spacings of $0.9 \mathrm{~m}$ yielded $29 \%$ to $34 \%$ more than did watermelons planted at in-row spacings of $2.1 \mathrm{~m}$. When deciding on pollinizer ratio using data from the current study, one must consider that increasing row width beyond $1.5 \mathrm{~m}$ may slightly modify calculations of yields. The current data indicated that when distance from the pollinizer row approached $6.0 \mathrm{~m}$, triploid fruit number declined sharply. Therefore, if growers use $1.8-\mathrm{m}$ row widths, perhaps a ratio of $1: 3$ would be best.

In summary, triploid watermelons do require a pollinizer and adequate pollinator insect activity for successful fruit set. Growers should realize that exceeding distances of $6.0 \mathrm{~m}$ from the diploid pollinizer will probably reduce yields. Also, planting too many pollinizers (i.e., ratios of 1:1 and 1:2) will reduce triploid yields. The results presented here suggest that triploid yields per unit land area would be optimized using a ratio of 1 pollinizer row : 4 triploid rows for $1.5-\mathrm{m}$ row widths.

\section{Literature Cited}

Karst, T. 1990. Seedless watermelon sure to grow. The Grower 23(8):61.

Kihara, H. 1951. Triploid watermelons. Proc. Amer. Soc. Hort. Sci. 58:217-230.

Marr, C.W. and K.L.B. Gast. 1991. Reactions by consumers in a farmers' market to prices for seedless watermelon and ratings of eating quality. HortTechnology. 1:105-106.

Maynard, D.N. and G.W. Elmstrom. 1992. Triploid watermelon production practices and varieties. Acta Hort. 318:169-173.

Mizelle, W.O., Jr. 1988. Commercial watermelon production. Coop. Ext. Serv. Publ. B-996. Univ. of Georgia, Athens.

NeSmith, D.S. 1993. Plant spacing influences watermelon yield and yield components. HortScience 28:885-887.

Parsons, J., L. Stein, T. Longbrake, S. Cotner, and J. Johnson. 1992. Seedless watermelon production. Agr. Ext. Serv. Bul. L-2303. Texas A\&M Univ., College Station. 